\title{
Development of Conflict Management Model Based School at Junior High School
}

\author{
${ }^{1}$ Muchsin, ${ }^{2}$ Hambali

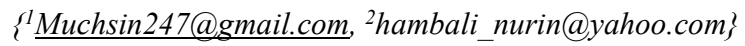 \\ ${ }^{1,2}$ Lecturer at FKIP USM
}

\begin{abstract}
This paper aims to find whether the cause of conflict in the school environment, how the style and techniques of conflict management in juniorhigh school, whether the approach in conflict management in the school environment and the influence of the model of Conflict Management on the Job satisfaction form Teachers. Conflict is a process conflict that is expressed by two or more parties. The conflict is influential all the components in the school. Therefore, the leaders and teachers must have mastered the management of conflict that arises can have a positive impact on improving the quality of schools. Furthermore, the authors want to develop a model of conflict management based school. This model is the techniques of resolution or stimulation to produce the desired resolution, especially on the development of a Model of Conflict Management Based School that is focused to give birth to a formulation of the instruments. Based on these findings, it was concluded that teacher job satisfaction can be increased as the conflict management and the empowerment of teachers by the head of the school is increasing. The results of this study can also be useful to improve the quality of conflict management and the empowerment of teachers by the principal to increase teacher job satisfaction overall.
\end{abstract}

Keywords: Model Development, Management-Based School, and junior high school.

\section{Introduction}

The success of an education process is determined by the success of the implementation of education management including human behavior in the scope of the education organization, human behavior in an education organization determines the success of education. So that, it is needed a good and proper management. Educational components consisting of pupils, teachers, principals, and other educational people, parents/guardians. They so find the success of education management since activity planning, implementation up to coaching and controlling. A teacher is one of education part has to influence the achievement of the educational goals. In the education process, the role of a teacher in the running task is as a teacher and an educator that is giving a number of learning materials to students. Even though, as an educator role as guide and nurture to become an accomplished man, active, creative and innovative. The task of the teacher is as a lecturer and educator are responsibilities as a professional power. So that, the role and the tasks can't only be carried out by teachers that 
have high professional competence. That's the attitude, the professionalism for a teacher is very to determine the success of the educational process. Professional competence teachers are influenced by internal factors. For example, a teacher's personality in the doing of the duties and responsibilities are accompanied with high motivation and loyalty in the guiding and nurturing students in the learning process teaching. And then, external factors have influential to the professional competence teachers, namely the leadership of the principal.

School as a response to the educational process in schools. The task of a principal is responsible for the implementation of the various activities of the educational process in schools e.g. how to manage several problems about the implementation of the school administration, the construction of the educational.

In the implementation of his responsibilities and principal daily activities often faced problems of both internal and external nature, so it takes good management in response and resolving the issue. The issue is a problem that is emerging from a conflict among teachers/pupils/students, employees, the environment. In our daily activities, there is the effect of the student's background, economy, culture, and victims of the conflict because of war.

The control of conflicts is one of the principal responsibilities in leading the school, and it can be seen when the principal is able to control and manage conflict. And then, when the principal is not able to control and manage conflict it would happened sense of dissatisfaction against the leadership of the principal, whether that comes from students, teachers as well as existing staff in the schools. Of course, it is desirable the principal as responsible in the school plays an important role to resolve issues of conflict faced, conflict management.

If conflicts can be controlled as good as possible and then it could give impact positive, profitable and beneficial for the school, such as 1) creating creativity, 2) constructive social change, 3) build alignment groups, 4) the improvement of the function of family and togetherness (Veitzhal. 2009:749). Therefore, the principal must have the ability to control and manage conflict with good and true. The principal has good competencies will pursue to improve the quality of existing resources with the empowering potential of them to improve the quality of educational process especially teacher's capabilities. Teacher's empowerment has done by principal either operational or structural will be able to give a great effect on the success of the school.Empowerment is conducted in the school is no different with the goal of empowering other organizations. They have goals required in order for the goal achievement progress effectively and efficiently by involving the resources in the school as proportionately. It means that the division of tasks is based on the duties and responsibilities of a mutually agreed. The successful principal in the empowerment of teachers will positively impact the school. It will be felt by teachers who have the potential and competence and that can be empowered by the school in the learning process as well as other administrative processes. But, we realize that there are still many principals who are not yet able to do empowerment to the teacher so that the potential and capabilities of teachers cannot be seen.

\section{Literature Review}

Every person in an organization or group have an interdependence in creating cooperation and an effective working relationship to the goals can be achieved. The dependency among the person with other people either in communications, information or coordination, where this cooperation can improve the performance of an organization or maybe increase to conflicts. One the example is commonly found in the world of education is a principal could collect the entire teachers and his staff to meet and discuss how to improve the quality of learning at school. This routine meeting will be caused 
without any conflict decision on the agreement. So that everyone who has been given the task and the responsibility can be run in harmony with the tasks assigned, but it is possible that this situation may be rise to the conflict of miscommunication and the division of tasks is not right so a contradiction between each other. Conflict in the organization especially in the environment of educational institutions took place in many varieties involving among people and groups relationships. Different views can often cause conflict so that the difference should be avoided.

The conflict is a process that arises when a party to the other party generally assumes that they have a negative affect something as being of concern other parties. Schermerhorn Friday, Hunt and Osborn (2005; 338) argues that "the conflict occurs when parties disagree over substantive issues or when emotional antagonisms create friction between them" (conflict occurred when problems do not share so that raises the conflict emotionally and created conflicts between them)

Basically, the process of the conflict begins when one party can't receive against any decision of the other parties especially in performing job duties, so that this conflict can cause discrepancies between two or more members or groups (within an organization /company) which divide limited resources or work activities or that they have a difference in status, purpose, value or perception. According to Wirawan $(2009 ; 5)$ stated that the conflict is a process of opposition expressed in between two or more parties to each other depending on the object of the conflict, using patterns of behavior and interaction of conflicts that generate output conflicts.

\subsection{Conflict Management}

Conflict management is very influential towards for all members of the organization of school organizations as well as other organizations. The principal conflict management controls required in order for the conflict that appears can positively impact to increase the quality of education in schools. The conflict cannot be solved certainly would impact the Organization, where such impacts include:

1. Conflict can cause the weakness working group and various jobs within the organization or company.

2. Conflict can lead to personal issues among people in the organization, if the conflict has already led to the question of personal, it would have had difficulty for the organization/company to be professional and to distinguish among matters the organizational and personal so that the performance of the organization will be uninterrupted

3. The conflict has had a positive impact when a manager or leader can manage the conflict be healthy competition among people so that the performance of the organization thus can increase. However, a prerequisite in order for the conflict to become a positive impact is a strong leader and manager roles in the organization.

Conflict can lead to a variety of things that are not directly related to the purpose of the organization appearing, so it is possible for the occurrence of a waste of time, money, and various other resources (Ernie. 2005; 291).

\subsection{Types of Conflict}

Some facts prove that the conflict within an organization usually is not able to produce things that are positive. But the conflict situations can be something that benefits when used as an instrument of change or innovation. Conflict can occur anywhere, especially in an organization, so it is needed a conflict management to control and resolve conflicts that occur. According to [1], Konopaske and Matteson (2006; 43) divided the conflict as follows: 
1. Functional conflict is a confrontation among groups that can increase performance and profitable organization. For example, two departments within a hospital debating how the most efficient and most adaptive to give health services to low-income families who live in rural areas. Both of these departments have the same goals but different ways. Functional conflict may increase awareness of the organization will be the issues that must be addressed, pushing the search solutions more broadly and more productive and often help positive change, adaptive and innovative.

2. Dysfunctional conflicts are any confrontation or interaction between groups' organizations that endanger or hinder the organization in achieving its goals. Management must find a way to drop the dysfunctional conflict

In addition to the conflict can also be classified based on various criteria, Wirawan divides the types of conflict as follows:

1. A conflict of Personal and Interpersonal Conflict. Personal conflict is a conflict within the person because of having to choose from a number of alternative options exist or because having multiple personalities.

2. Conflicts of interest occur between people, officials or social systems with greater personal interest than organizational interests thereby affecting the performance of their obligations in carrying out activities

3. Realistic Conflict and conflict of a Non-realistic. Realistic conflict is a conflict due to differences and does not agree how the achievement of the goals or goals that will be achieved on. Unrealistic conflict is a conflict not related to the issue of the substance of the cause of the conflict. The conflict is fueled by hatred or prejudice that encourages aggression to beat and destroy opponents of the conflict.

4. Destructive conflict is a conflict that involves the groups and it is not flexible or rigid because the goal was defined narrowly each other. Constructive conflict is a conflict that the process leads to finding solutions to the conflict, and it is built the new situation of the groups involved in the conflict.

5. According to conflict areas, there is some conflict object such as economic, political and religious.

\subsection{The Causes Of Conflict}

A conflict that occurs is usually caused by some reason, as the communication factors, this reason may lead to the occurrence of conflict when the members of an organization or among organizations cannot or don't want to understand each other and mutual understanding in a variety of things in the Organization, the occurrence of misunderstanding when communicating can also lead to conflict. Wirawan $(2009 ; 137)$ said that conflicts can occur naturally due to objective conditions that can cause the onset of the conflict. There are some sources that can cause conflict is 1) limitations of the source, where the humans always have the limitations of the resources needed to support life, so these limitations may cause conflict, 2) goals that happen because the parties involved conflict has different goals, 3) interpendention task, occurs because the parties involved conflict has a task that depends on each other, 4) difference organization occurs because of the division in the bureaucracy of the organization and specialization of labor practice, 5) ambiguities jurisdiction is division of tasks, not definitive obscurity would cause the scope of duties and authorities of work units in the organization, 6) system rewards are not possible, usually in the company of using a reward system that is considered unjust, unworthy or not equities by employees, 7) communication is not good and it often gives rise to conflicts such as the use of language that is not understood in communication 


\section{Results And Discussion}

\subsection{The Causes of Conflict}

A conflict that occurs is usually caused by several factors, including due to communication (communication factors), this reason may lead to the occurrence of conflict. The members of an organization or between organizations cannot or don't want to understand each other and mutual understanding in a variety of things in the organization, the occurrence of misunderstanding as communicating can also lead to conflict. There are some sources that can cause conflict is 1) limitations of the source, where the humans always have the limitations of the resources needed to support life, so these limitations may cause conflict, 2 the goals happen as the parties involved conflict have different goals, 3 ) independent task occurs as the parties involved conflict have a task that depends on each other, 4) differentiation organizations, occurs because of the Division of tasks within the bureaucracy of the Organization and specialization of labor practice, 5) ambiguities jurisdiction, Division of tasks, not definitive obscurity would cause the scope of duties and authorities of work units in the Organization, 6) system rewards are not possible, usually in the company of using a reward system that is considered unjust, unworthy or not equities by employees, 7) communications are not good, not good communication often gives rise to conflicts such as the use of language that is not understood the parties communicate.

\subsection{Conflict Management Styles and Techniques}

A leader of the organization or company managers both individually and group in the face of many conflicts faced or found in the organization. So that, the conflict is resolved or unresolved surely developed a management style the conflict. The conflict management style is very dependent on the leadership. Conflict Management Style, there are five ways to handle conflict style is right for particular cases as follows:

1. Style competed; reflecting the firmness to get the desired and should be used as the action is fast and firm is indispensable to the important issues or actions that are not common as at the time of the emergency or urgent cost-cutting.

2. Avoid Style; not show firmness or cooperative. This style is used when the issue faced by the trivial, there's no chance of winning, the delay to get more information is needed or the mess will costly.

3. The style of compromise; reflects the number of assertiveness and cooperative. This style is used as the purpose of the two parties are equally important, opponents have the same powers and both parties want to compromise, or when people must get a temporary expedient or various solutions under certain pressure.

4. Style accommodating; show a high level, which is suitable when people realize that they are wrong, an issue more important for others than for themselves, build social awards to be given in subsequent discussions and when maintaining the harmony is crucial.4. Style accommodating; show a high level of cooperative, which is suitable when people realize that they are wrong, an issue more important for others than for themselves, build social awards to be given in subsequent discussions and when maintaining the harmony is crucial.

5. Style collaborate; show the level of assertiveness and cooperative. The style allows both parties collaborate to win, although it requires a lot of bidding and negotiations. The style is important when the issue of collaborating parties are too important to the discussion of 
insights from different people should be merged into a comprehensive solution and when the commitment of the parties required for consensus

Conflict management techniques, conflict management technique is a technique that is done to influence the conflict so that the opponent can produce the expected output. Conflict management techniques can be used in the event and the parties involved it can do together depending on the conflict situations met, if the parties to a conflict to use the desired engineering is not successful it will be in use other techniques to solve and control conflicts.

The technique of Solving Conflict, the conflict resolution techniques, namely:

1. problem solving: face-to-face meetings the parties in conflict with the intent of identifying and solve it through discussion of open.

2. Target tops: Create shared goals that cannot be achieved without the cooperation of their respective parties in conflict.

3. Expansion of resources: When a conflict caused by the scarcity of resources such as money, promotion opportunities, the Chamber Office-extensions of resources can create winner

4. Avoidance: withdraw from conflict or pressing. Expansion of resources: When a conflict caused by the scarcity of resources such as money, promotion opportunities, Officeextensions of resources can create winner

5. Masking: Ignore meaning differences while emphasizing the shared interests between the parties in conflict

6. a compromise: each of the parties involved sacrificing something valuable

7. authoritative Command: authority format using the Management to resolve conflicts and then communicate a willingness to engage

8. change the variable man: using the technique of modifying human behavior such as human relations training to change the attitudes and behaviors that lead to conflict

9. structure of the variables Change: changing the organizational structure of the formal and structural patterns of interaction of the parties in conflict through the remodeling job, transfer, creation of coordination positions and such.

Excitation Techniques Conflict, while the technique of Excitation the conflict, namely:

1. communication: Using messages that are ambiguous or threatens to raise the level of conflict

2. Enter the outsider: adding employee backgrounds, values, attitudes or different styles with group members

3. Restructuring of organization: reset teamwork, change the order and regulations, increase mutual and structural changes made similar to destabilize the things as they are

4. Appoint opposition: pointing to deliberately defy the greatest held by the group. In the face of conflict, the parties involved conflict can also use a variety of tactics, as follows (Wirawan, 2009, 148):

1. Rational persuasive tactics by influencing conflict with opponents argued the data, information, facts or theories of scientific knowledge, good or bad

2. The legitimacy of tactics used by officials who occupy certain positions legitimately

3. Tactics request inspiration; suggested values, norms, self-esteem and the unity of the Organization to arouse emotions, motivations and goals along with autopsy tactics

4. Give the title, place or certain roles to opponents of the conflict to take part in resolving conflicts

5. Exchange of tactics; promises to deliver something or not giving something in return if the opponents behave certain conflicts 
6. Friends looking for tactics/Coalition; generally done by parties involved in conflict with power or weaker place to the opponent of the conflict

7. Silent restraint tactics; don't do something you should do, not react to what the opponents of the conflict

8. Tactics cry or call upon; shows the helplessness of the opposing parties involved conflict face opponents of the conflict threatening tactics

9. Using the tactic of threatening to do something or not related to the employee

10. Tactic of lying; something honest bias turns into a liar if his place is deliberately stalling tactics

11. Put off doing something or refusing to respond to conflict in conflict interaction of opponents.

\subsection{The Approach in the Management of Conflict}

According to Tisnawati and Saifullah $(2005 ; 292)$, a conflict so as not to damage the structure and performance of the organization then we recommend that you do approach or efforts in controlling and solving the conflict. In the management of conflict can be supervised and controlled was owned directly. So that it remains can be directed to support the achievement of business aims of the Organization through better organizational performance. The third approach is to download the stimulus, namely stimulating conflict, controlling conflict and registrar and eliminating conflict of the conflict is essentially an effort conducted by the Chairman/Manager against a conflict with the road give stimulant that causes the parties involved conflict of directing the conflict to something that is positive for himself and the organization. Among the programs being run is positioning the parties involved conflict into a situation where they are engaging in a positive competition will improve their performance and organization. Enter a reason in this competition can be done with certain compensation bid so that the parties involved conflict will actually do the competition between them, the offer may include bonuses, incentives or in the form of other compensation. Other forms of stimulation are also commonly done is to make changes to rules or rules that apply within the Organization, with the hope that the parties involved conflict can make adjustments so that the position of conflict can be resolved. In addition to giving stimulation to the parties involved in the conflict, another approach is the control of conflicts. Conflict control is carried out to make sure that the conflict can be constantly avoided. The usual program does is through an expansion of the use of resources of the Organization, a conflict that is caused because of the use of resources can be addressed by expanding the use of resources, in addition to improving coordination can also be performed a the tar part within the Organization, moreover, it can also do the adjustment behavior of workers with what should be running the company/organization through provision enacted. In order for the conflict remain directed towards the achievement of a better organization of the performance, it is necessary a settlement or avoidance of conflict that occurs, such as, two people or groups who will be reunited when conflicting conflicts, then there needs to be a separation of their two parties such as the Division of the different employment job or work time that is not concurrent. And the best way is to bring together the parties involved in the conflict to do a compromise in resolving the conflict.

\subsection{Conflict Management Based School}

Conflict management is indispensable in conflict control to produce the desired resolution. The principal is crucial to the context and resolves the conflict itself as well as the conflict for the school, for one of the conflicting parties or benefits himself in the face of the conflict. 
Good conflict resolution and can benefit all parties are expected of everyone. One important factor in providing job satisfaction forms teachers is the leadership of the principal that can lead and manage some schools that give to the conflicts that arise from school. It is hoped that resolving conflicts by giving satisfaction with your teacher is able to produce good achievement. Job satisfaction from teachers can also be delivered to the empowerment of teachers. The amount of attention on the principal to improving the quality and competence of teachers will be able to increase the potential that can be developed optimally. Principals by empowering teachers and in accordance with the expected goals will be able to offer results to improve teacher work results. Higher work outcomes the symptoms that work well and responsible.

\section{Conclusion}

1. There are some sources that can cause conflict, namely resources limit, different goals, interdependence, differentiate tasks, organization, ambiguities jurisdiction, the reward system is not possible, and that communication is not good

2. There are five styles of how to handle conflicts according to specific cases as styles, styles competed to avoid compromising style, style, accommodate, force collaborate. While conflict management technique is a technique that to influence the conflict so that the opponent can produce the expected output

3. There are three approaches to the management of a conflict, namely stimulating conflict, controlling conflict and rregistrar and eliminating conflict

4. Conflict management model based school is the techniques of resolution or stimulation to produce the desired resolution.

\section{References}

[1] M. Ivancevich John M, Konopaske, Perilaku dan Manajemen Organisasi. Jakarta: Gelora Aksara Pratama, 2006.

[2] Daft, Richard L. 1999.Leadership; Theory and Practice. New York. Harcourt Brace College Publisher

[3] Fajar, Malik H. A. 2001. Platform Reformasi Pendidikan dan Pengembangan Sumber Daya Manusia. Jakarta. Logos wacana Ilmu

[4] Irawati D. 2007. Manajemen konflik sebagai upaya meningkatkan kinerja team work dalam organisasi. Segmen Jurnal Manajemen Bisnis, (2):15-27.

[5] Kwantes CT, Karam CM, Kuo BCH, Towson S. 2008. Organizational citizenship behavior s: The influence of culture .Journal of Inter cultural Relations, 32:229-243.

[6] Makmun, Abin Syamsudin. 2008. Profesionalisme Guru Sebagai Sebuah Kebutuhan Materi Pelatihan Tingkat Nasional Pedagogik Guru. Bekasi. ISPI, UNJ

[7] Muchsin, 2013. Manajemen Pembelajaran Bahasa Inggris pada Jurusan Pendidikan Agama Islam (Studi pada Fakultas Tarbiyah Universitas Serambi Mekkah Banda Aceh), Serambi Tarbawi, Vol.1. No.1, hal107-136

[8] Rivai, Veitzhal dan Sylviana Murni, 2009. Education Management; Analisis Teori dan Praktik. Jakarta. Rajawali Pers

[9] Robbins, Stephen P. 2000. Essentials of Organization Behavior, New Jersey. Prentice Hall.

[10] Sugiono. 2006. Metodologi Penelitian Pendidikan. Bandung. AlfaBeta

[11] Sule, Trisnawati dan Kurniawan Saefullah. 2005. Pengantar Manajemen. Edisi Pertama. Jakarta. Prenad 